\title{
In the Market for Symbolic Commodities
}

\author{
Swedish Lottery Game Show 'Bingolotto' \\ and the Marketing of Social and Cultural Values
}

\author{
GÖRAN BOLIN
}

Historically, the broadcast media in Sweden and the Nordic countries have been organised around strong public service institutions. In a European perspective, Sweden, together with Denmark and Norway, has also been among the last to abandon the public service model and open the system to commercial competitors (Hultén 1996 p. 10). However, since the late 1980s the Nordic countries have seen deep and thorough changes in their radio and television systems. The deregulation of the public service monopolies in the wake of the introduction of transnational networks via cable and satellite, and the fragmentation that has followed from the enormous increase of new media technologies and content, have shaped the Nordic countries into multimediatised electronic landscapes. This has naturally changed the structures of media organisations (cf. Curran 2000), and has affected output structures both quantitatively and qualitatively (cf. Asp 2001 for a Swedish example). These changes have involved radically changed conditions for the production of broadcast content, perhaps especially for television. And it is probably not overstating the case to say that social and cultural effects will continue to follow in the wake of these processes, and that the consequences of these changes are yet to be discovered in full.

Quantitatively there has been an increased output in the broadcast media: more channels, more programmes, more possible viewing hours, etc. The demand for programmes to fill radio and television schedules has, firstly, speeded up the production process, to the benefit of productions that can be serialised, in the system of production that John Ellis (2000) describes as demand-led.

A second consequence of the new media geography, and the quantitative increase in output, is the rise of new genres and programme formats. One such new format that was launched when Sweden got its third terrestrial, national, and for the first time commercial, television channel (TV4), was Bingolotto. The introduction of TV4 in 1991 meant that viewers in all parts of the country could watch commercial television. Bingolotto allowed Swedish viewers to take part in a game and entertainment show with a level of prizes that had been impossible to air on the public service channels SVT1 and SVT2. The Bingolotto show, originally produced for a local television network in the Gothenburg area with the aim to help local sports associations financially, has since its start on 
national television in October 1991 been aired live at prime time on Saturday evenings. It is usually broadcast between 19.00 and 21.00 , but is occasionally extended for special occasions (monthly finals, the night before Christmas Eve, etc.). Thus the programme is just as old as TV4, and is one of the programmes that have made up the core of the channel's programming (together with syndicated shows such as Jeopardy). The popularity of Bingolotto and other shows has led to TV4 being the largest single television channel in Sweden since 1994, if counted by audience share.

A third effect of the introduction of commercial broadcasting is that more organisations and collective agents have been involved in television production (cf. Robins \& Cornford 1992). ${ }^{1}$ When the Nordic public service organisations had a monopoly position, the majority of domestic programmes were in-house productions, made by people employed by the media corporations, and often at their own production units. This is far from the case within commercial television, where production and distribution tends to be separated. Thus, the deregulation in Sweden and the Nordic countries paved the way for new media production enterprises. Subsequently, these enterprises have come to serve both the commercial television channels and the public service channels, thus changing the production practices not only in the commercial sector, but also in the remaining parts of the public service sector. The deregulation of the media market made entrepreneurial initiatives possible, and the expansion of the market for symbolic production also meant that people with little or no experience in media production could enter the field (cf. Paterson 2001). Bingolotto is the result of one such entrepreneurial initiative that has ultimately changed the structure of the field of television production and distribution in Sweden, where initiatives from regional sports societies with an interest in local television broadcasting have launched a programme to support their activities economically.

However, there have also been qualitative changes in the system - changes that concern the characteristics of the programmes produced. Naturally, some of these qualitative changes are connected to the quantitative changes. More programme hours lead to faster productions, which makes media production more industry-like, in an assembly line kind of way, where game shows are produced in series of a couple episodes per day (cf. Adorno \& Horkheimer 1947/1979). This naturally affects the programme content, in that the programmes must fit into this mode of production (you cannot spend time on long rehearsals, etc.). Thus certain kinds of programme formats tend to be privileged. But this also affects the aesthetics of the programmes produced, in that sponsor demands enter into the process (e.g., product placement). As Bingolotto is a programme centred around a lottery game with sponsor-financed prizes, such features are, as I will show in greater detail below, evident.

Another thing that affects the production process qualitatively is the fact that the different interested parties that become involved in the production are of different kinds, and that their interests therefore differ. This is especially so in a complex production like Bingolotto. Besides the usual parties involved (advertisers, sponsors, television channel stock owners, media production enterprise owners, programme production staff, etc.), there are more unusual parties to be found. One such party are the Swedish 'popular movements' (folkrörelser), ideal, non-profit associations that distribute and sell the lottery tickets that viewers use when they play the lottery game bingolotto on Saturday evenings while watching the programme Bingolotto. ${ }^{2}$ Economically, Bingolotto helps in subsidising the activities of the popular movements since a third of the lottery ticket sales goes back to the selling association. Since the yearly lottery turnover for the last six to seven years has been around 3 billion SEK, this means that Swedish popular movements (mainly the sports movement) generate a bit over 1 billion each year. The proportions 
could be illustrated by the fact that TV4, as the distributing channel, had an all-time high turnover in the year 2000 of 2.5 billion SEK.

Ideal associations are by nature non-profit, and are driven by other motives than are commercial organisations. One of the founding aims of commercial production, generally, is to create economic surplus value. However, the media commodity differs from several other commodities produced for commercial markets, since its form is non-material. A car has a material form, which gives it a certain characteristic in shape and in performance. These characteristics become charged with values in the social circulation of the product or commodity. Beside its material form it thus also has symbolic form, to which in social practice is conferred values to add and contribute to its exchange value, e.g. social, political and cultural values. An argument sustained in this article is that those symbolic values tend to be more important in non-material media production. And, furthermore, that the combination of these values in the case of Bingolotto is beneficial for capitalist commercial media production.

Although the everyday production practices of making a television entertainment show might not differ (you need a camera, editing facilities, a studio, etc.), the conditions under which commercial media television programmes are produced nonetheless dictate that the programme texts differ from those produced within public service systems. As the ultimate aim in a public service broadcasting system is not to create surplus value, but to create other kinds of values (social, cultural, political), the products produced take on different form, and must be analysed from different perspectives.

In the following I will, against the background of a Swedish broadcasting system in the process of change from a public service model to an increasingly commercialised business, discuss the products and commodities produced in and around the television programme Bingolotto, and the values with which they are bestowed. I will organise this discussion in three parts. Firstly I will give a historical background to the programme, with a special focus on the organisation of the national lottery 'bingolotto', and on the television programme Bingolotto. I will also give some background information on the development of the programme and describe changes in audience size and structure, connect this to changes made in the programme and in the lottery, and discuss how this affects the lottery turnover. Secondly, I will discuss the different interested parties in the lottery and the programme. This discussion will focus on the products, commodities and values produced. I will start with FSL, the body that organises the lottery and represents the Swedish popular movements, then follow the production chain to the production enterprise Interactive Gaming Systems (IGS) ${ }^{3}$ the distributing television channel TV4, the other interested parties such as the Swedish state, the advertisers and sponsors, and last but not least, the viewers. Thirdly, I will discuss the relations between the interested parties, and what effects these relations bear on the programme text. I will also discuss this at the level of internal relations within some of the interested parties, as they on an individual level sometimes carry conflicting interests and aims with the activity of producing the lottery and the show. I will end this part with a discussion on the interplay between the commodities and values produced in the process, and make some general conclusions on television production within a broadcasting landscape under transformation to an increasingly commercialised system.

I base my discussion on a wide range of material comprised of interviews with production staff (producers, programme hosts, technicians, etc.), managerial staff at the production enterprise IGS as well as at TV4 and FSL, and people involved in lottery distribution. The material also includes observations from programme production, and 
interviews and participant observation among viewers. Furthermore, the discussion involves quantitative data on lottery distribution, reach and turnover by FSL, and audience statistics from FSL, TV4, ACNielsen and MMS. The project has also involved qualitative analysis of programmes, focussing on generic and narrative change and audience address. A more detailed presentation of the material and its related methodological considerations can be found in Bolin \& Forsman (2002).

\section{Bingolotto - The Historical Context}

Bingolotto was launched as a local television programme, broadcast via cable over the Gothenburg area in the middle of autumn 1989. In October 1991 the first national version was aired on the then-newly launched third terrestrial national channel TV4, produced by the same enterprise and staff in Gothenburg who had been working with the programme locally. Having been of local concern for two years, the programme became a huge national success and the special Saturday event for millions of Swedes. It has since been aired in around 400 episodes nationally, and almost equally as many locally, since it was aired simultaneously on local television (on Tuesday evenings), with the same host and producers, until May 2000. The programme runs each Saturday for forty weeks per year. There is one short break during the Christmas holidays and another between the spring final in the beginning of June and the autumn opening in late August. This means that the show is among the most long-lived in the history of Swedish broadcasting, with a popularity and audience appeal that can only be compared to some of the most popular shows within SVT, e.g. Hylands hörna, a programme aired between 1962 and 1983, although not continuously. Bingolotto also shares other features with this predecessor, among other things in the immensely popular host Leif 'Loket' Olsson, who, just as his older colleague Lennart Hyland, had a way of talking to people about ordinary matters and making conversation about the weather and daily routines sound interesting. They also shared the feature of having started out as sports journalists in radio, and both had long experience of non-sport radio talk shows. However, there are also differences between them. Hyland had a more US-inspired way of hosting (and had also made trips as early as 1958 to the US to study game shows before he launched his own, cf. Sjögren 1997 p. 242). In contrast to Hyland, Olsson put a strong emphasis on features of Swedishness, often giving prominence to typically Swedish phenomena.

The basis for the television show is the lottery 'bingolotto'. Just as the name indicates (in Swedish as well as in English), the game is a combination of bingo and lottery. The combination is due to the fact that Swedish law prevents live lotteries on television. Thus the bingo part of the lottery is a complicated, but to many viewers entertaining, way of checking if the number on the lottery ticket has won. The numbers have actually been drawn beforehand, but kept secret in order to preserve the illusion that they are drawn live, creating the suspension that the game builds upon. Each programme consists of three bingo/lottery games (five in the local programme). In addition to this, those who have managed to get five numbers in a row (bingo), can call into the studio to win more prizes, or to become special guests in the next week's programme. Prizes consist of consumer goods such as food, snacks, coffee, petrol, clothing, furniture, electronics, vacation trips (often to destinations considered exotic by Swedes, such as Thailand), etc. But there are also more expensive prizes such as cars and cash up to several million SEK - the largest being 16.5 million SEK. Between the telephone calls and additional lottery draws artists perform. 
Having been broadcast for more than ten years nationally, Bingolotto has gone through several changes. The most evolving change was probably in 1999, when the original programme host Leif 'Loket' Olsson was replaced by Lasse Kronér, a song and dance entertainer and, just like Olsson, a local personality in the Gothenburg area. Kronér shares with Olsson the same pronounced dialect, which places the programme in a distinct local, or regional, context. With the change to the somewhat younger Kronér also followed a new audience address, set design, a change in the colour scheme of the programme, and, not least important, a change in the artist profile. From the beginning, a standard feature of Bingolotto was its concentration on Swedish 'dance orchestras'. These orchestras are known for their broad repertoire of popular songs, and usually play at weekend dance venues, mainly in small cities and in the countryside. The phenomenon is restricted to Sweden and Norway, and this type of music is largely despised by urban youth and among those with higher education (cf. Bjurström 1993).

Possibly as a consequence of this, Bingolotto seems to be of typical Swedish concern. Several attempts have been made to export the format, but almost all have failed. There have been successful attempts in Germany, but otherwise it has not met with success even in the neighbouring Nordic countries.

The change in 1999, whose ultimate purpose was to reach younger and more urban audiences with greater purchasing power, was to a certain extent successful for the producers. Having had its largest audience among the age group 60+, the 'new' programme succeeded in attracting somewhat younger people, i.e. the 20-44 year age group. This group includes a third of Sweden's population, and most important for TV4, the 'families with young children, who are major consumers of convenience goods', as Managing Director Thorbjörn Larsson of TV4 explains in the Annual Report of 1998 (p. 3). The symbolically important, but extremely hard to reach, audience group of teenagers and twenty-somethings have, however, never found the programme attractive.

\section{The Organisation of the Lottery and the Programme}

The national bingo lottery has had a total turnover of more than 30 billion SEK, which has given the Swedish popular movements around 10 billion SEK. Besides the revenue to the selling associations, a third of the turnover is returned to the lottery buyers in the form of prizes. The rest goes to the arrangements around the lottery organisation (distribution of tickets, PR, printing of tickets, etc.), and to the production of the programme.

The lottery game is organised by Folkrörelsernas Samarbetsorgan i Lotterifrågor (FSL), which is an alliance of around 60 ideal associations. In all, these associations have approximately 6,5 million members. Although there are people who are members in more than one association, this makes up quite a large proportion of Sweden's 9 million inhabitants.

The largest of the associations within FSL is the Swedish Sports Confederation, an 'umbrella organisation of the Swedish sports movement' that among other things represents member organisations 'in contacts with politicians, the government and other institutions/organisations', as stated in its web pages (www.rf.se, 020215). The member associations of this confederation are responsible for around $90 \%$ of total lottery sales. Of the different sports represented in the Swedish Sports Confederation, handball, football and ice hockey clubs make up the core of the distribution and sales of lottery tickets. Of the 'collective' sports, handball stands out as the most engaged in the handling of lottery tickets, which might be explained by the relative lack of interest in this sport from sponsors, at least compared to sports with higher media attention such as football 
and ice hockey. In all, around 220,000 people are involved in the handling of lottery tickets each week. A lottery ticket costs 40 SEK (spring 2002), and of that amount somewhat more than $30 \%$ goes back to the association that sells it, often a local sports club.

FSL has, for the purpose of organising the television draw, launched its own production enterprise - Svensk TV-Bingo AB - which formally produces the programme. Svensk TV-Bingo has commissioned the actual production of the programme to Gert Eklund Television (GETV), a company owned by the holding company Eklundgruppen AB. Eklundgruppen eventually merged into Interactive Gaming Systems, a company registered in the Netherlands, but of which $80 \%$ is owned by Gert Eklund. Eklundgruppen then became responsible for IGS' interests in Sweden (IGS was also engaged in Internet gambling and virtual casinos, which are activities that due to Swedish legislation cannot be operated from Sweden). The format was eventually sold to the Dutch company Novamedia in April 2001, whose main owner, Joop van der Ende, is known more for his association with the television production enterprise Endemol, which has a long row of internationally successful formats on its list of merits, e.g. Big Brother and All You Need is Love (cf. van Zoonen 2001). ${ }^{4}$

Behind all these enterprises and companies is Gert Eklund, who 'invented' Bingolotto after having been inspired by a similar programme on Danish local television. Eklund has a firm background in the regional sports movement in Gothenburg. He is often described as a person with entrepreneurial abilities and a strong dislike of central as well as local authorities and state regulations. He was also deeply engaged in local television production early on. Gothenburg is one of the regions in Sweden where local television broadcasting via cable was first experimented with, and the history behind Bingolotto is heavily intertwined with local television development in the Gothenburg area (cf. Björkemarken 2000).

TV4 was granted a licence agreement (koncessionsrättighet) to terrestrial broadcasting as Sweden's third national channel in October 1991, the same month as the premiere of Bingolotto. Terrestrial broadcasting began in March 1992, however. Until then, Bingolotto and all other programmes were broadcast via satellite. However, the symbolic value of having been granted this advantage over the commercial competitors should not be underestimated, and meant that the channel could make long-term investments and stake out plans and strategies for the future.

A prerequisite for being granted the licence agreement was that TV4 should provide a certain amount of locally produced material. When the discussions and bidding for the agreement was in full process, Gert Eklund was offering the programme concept to national broadcasters. The offer from Gert Eklund seemingly came in handy for TV4, as the company needed to develop local 'windows' in different parts of Sweden. Despite the character of the programme, which according to Eklund did not appeal to the staff from TV4, the offer on a regional window was evidently too good for TV4 to turn down. Eklund's desire for the show to be aired on prime time Saturday evenings also met approval, likely because TV4 did not have any better alternative at the time.

TV4 does not pay for the production of Bingolotto, or for the right to air the show. Instead it grants IGS the disposal of the slot between 19.00 and 21.00 on Saturday evenings. In return, TV4 gets a programme that attracts millions of viewers, and can sell its viewing time to advertisers. As the licence agreement holds that programmes cannot be interrupted by commercials, Bingolotto is not one programme each Saturday, but three programmes, interrupted by short programmes of around three minutes, around which can be placed commercials. The three parts of the programme have a total broadcast time of 
between 95-100 minutes, depending on how much advertising time has been sold by TV4. Each part of Bingolotto is around 31-35 minutes. After the first part there are a couple of advertising clips, then a three-minute programme (e.g., Om en bok [About a Book], where a celebrity tells about a favourite book of his or hers), then commercials again and then back to the next part of Bingolotto.

\section{Audience Statistics and Lottery Turnover}

Between autumn 1992 and spring 1997, Bingolotto had an audience rating of around 2 million viewers each week (with a drop in ratings during autumn 1993 and spring 1994) (Figure 1). ${ }^{5}$ The Christmas special programme of 1995 garnered 3,145,000 viewers, which is the highest rating in the history of the programme - and the all-time high for TV4 to date. Few television shows in Sweden can compete with such ratings.

Figure 1. Average Audience Size per Programme and Season 1991 - 2001

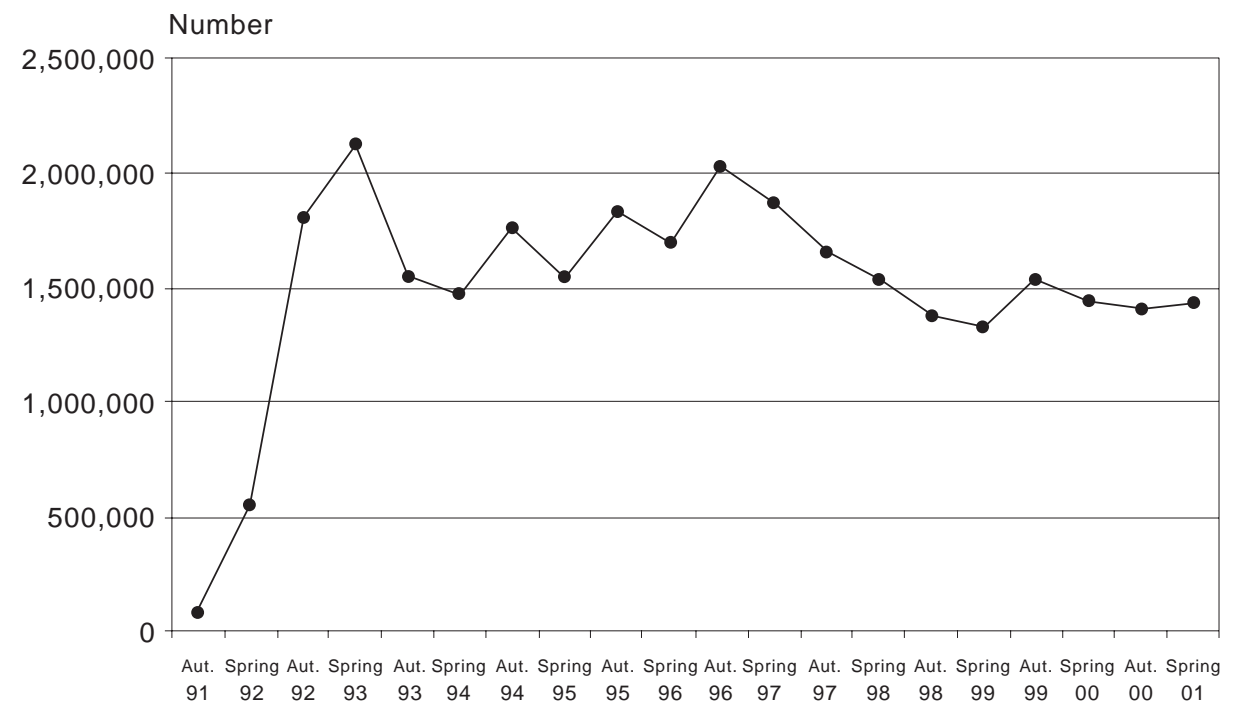

Having had such a large audience, Bingolotto has for periods been the most popular programme on Saturday evenings in Sweden. Through this, the programme has contributed to TV4 being today the largest single channel in Sweden audience-wise, not least in the target groups 15-45 years, the most attractive audience segment for sponsors and advertisers.

The correlation among audience size, lottery ticket sales and the turnover of the lottery is naturally strong. With many tickets sold, one can expect a large audience. This is also the case, as can be seen in Figure 2, in which the two curves are almost parallel to each other. ${ }^{6}$ Statistics produced by TV4's audience analysis department on two occasions (1995 and 1998) also show that only one percent of viewers watch without having bought a ticket. 
Figure 2. Audience Size and Ticket Sales per Programme Between Spring 1995 and Spring 2001. Peak Values Represent Season's Finals and Christmas Specials

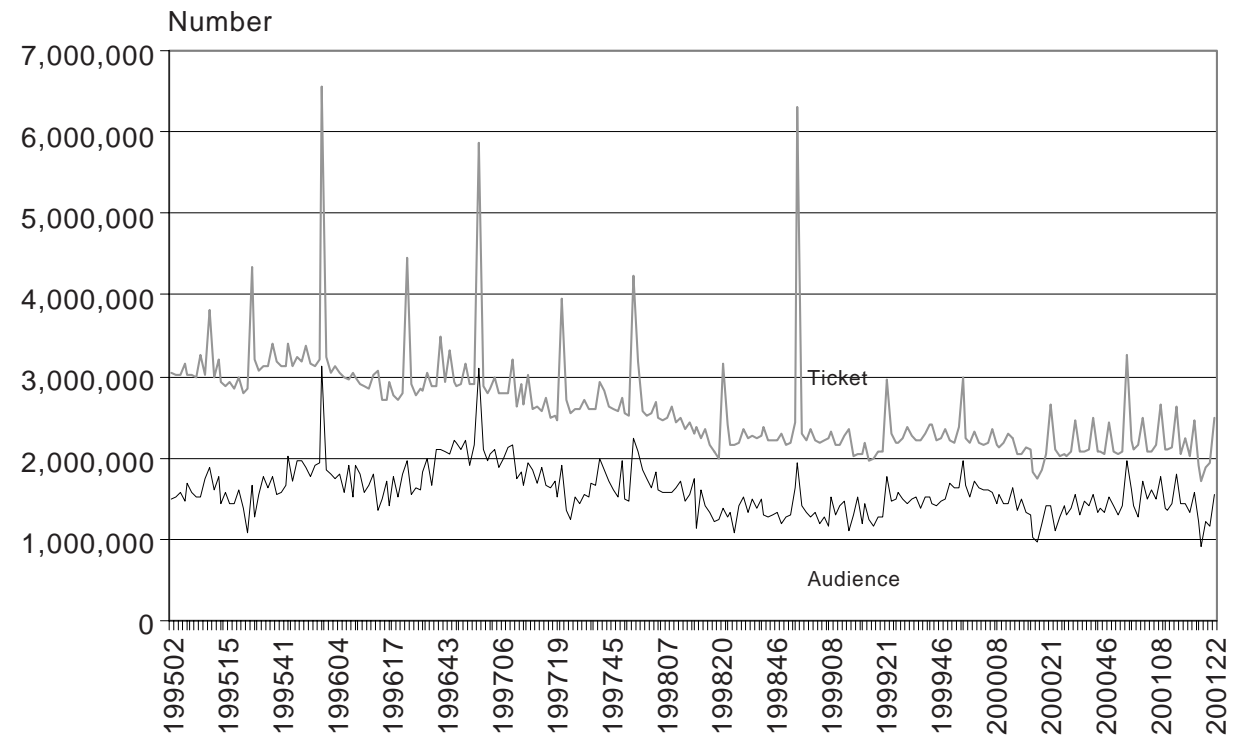

The relation among audience size, ticket sales and turnover is, however, not always straightforward. The size of turnover also has to be related to the price of the lottery tickets. Prices have been raised a couple of times over the years: in 1994 from 20 to 25 SEK, in 1996 from 25 to 30, and in 2001 up to 40 SEK. Ticket sales increased slightly on the first two of these occasions. However, due to the increase of the price of the ticket, turnover increased even more, as can be seen in Figure 3.

Figure 3. The Relation Between Number of Sold Tickets and Turnover (divided with 10 for increased comparability). Prices on Tickets Increased Before Autumn 1994 and Autumn 1996

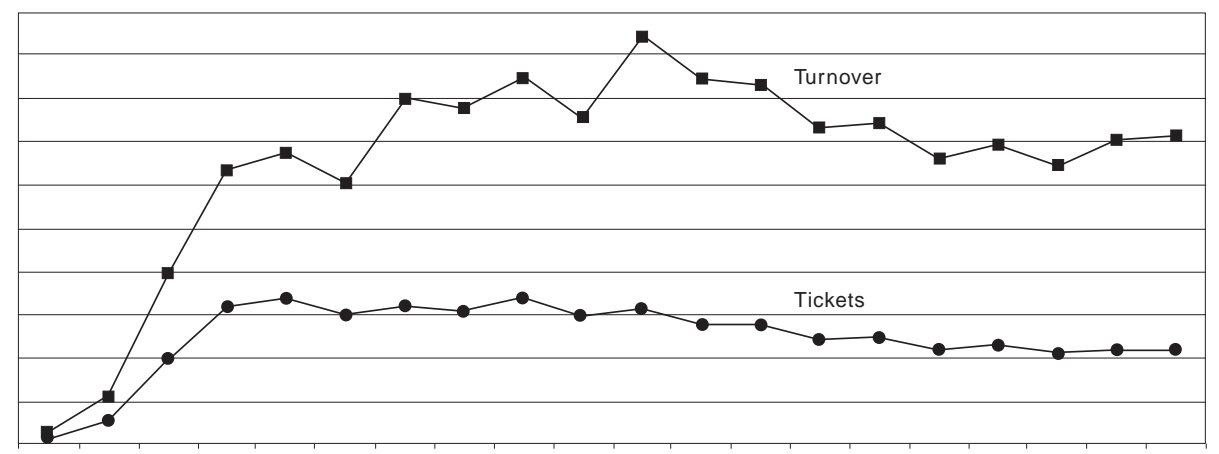

Aut. Spring Aut. Spring Aut. Spring Aut. Spring Aut. Spring Aut. Spring Aut. Spring Aut. Spring Aut. Spring Aut. Spring

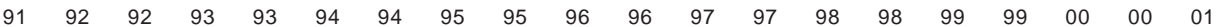


The decrease in number of tickets sold while there is an increase in the turnover during autumn 2000 and spring 2001 is not connected to any increase in prices. This is due to the introduction of a new 'double' ticket. The double ticket costs twice as much as the ordinary ticket (and gives twice as much to the selling association). In this way, the turnover increases more than would be expected if seen against sales figures of lottery tickets.

The most successful ticket sales season was spring 1993. The 63.7 million tickets sold amounted to twice as much as were sold the previous season. A comparison made between the years 1992 and 1993 show that the increase was 275\%. However, when compared with the turnover, it is possible to discern another pattern, in which the most successful year was 1997. From a turnover of 32 million SEK the first autumn the show was on air in 1991, turnover increased to 3.2 billion SEK in 1997 (which counted for a net revenue for associations of slightly more than 1.3 billion SEK, cf. Table 1). On an average each programme in 1997 had a ticket sale of nearly 2,8 million tickets, which meant a turnover of approximately 80 million SEK. In a study from 1996 it was estimated that $67 \%$ of the Swedish population had bought a lottery ticket on some occasion (Wicklin 1999). There is thus some truth in claiming the programme to be 'popular' (as in widespread) on the Swedish gaming market, and it is thus not surprising that the organiser FSL has re-branded itself 'Folkspel' (People's Game).

Table 1. Ticket Sales Turnover, and Net Revenue to the Selling and Distributing Organisations. Net Figures for 2001 are Preliminary

\begin{tabular}{lcc} 
Year & $\begin{array}{c}\text { Ticket sales turnover } \\
\text { (million SEK) }\end{array}$ & $\begin{array}{c}\text { Net revenue to associations } \\
\text { (million SEK) }\end{array}$ \\
\hline 1991 & 32 & 8 \\
1992 & 855 & 260 \\
1993 & 2,361 & 948 \\
1994 & 2,498 & 1,045 \\
1995 & 2,997 & 1,245 \\
1996 & 3,112 & 1,278 \\
1997 & 3,242 & 1,330 \\
1998 & 2,871 & 1,068 \\
1999 & 2,875 & 1,110 \\
2000 & 2,770 & 1,110 \\
2001 & 2,935 & 1,200 \\
\hline
\end{tabular}

Source: FSL.

Tempting the audience with the chance of winning minor as well as larger prizes (cars, cash, etc.) has been a way of both promoting lottery ticket sales and attracting large audiences. Around 400 people had won cash prizes of one million SEK or more by the end of the autumn season 2001 (and more than 30 have won prize sums of more than 5 million SEK. Cars as prizes have also been significant for Bingolotto. Almost 3,000 cars of different models have been drawn in the lottery.

Until the mid-1990s Bingolotto conquered increasingly larger parts of the Swedish gaming market, and during 1995 and 1996 the lottery was the largest in Sweden if measured by turnover. For a while it seemed as Bingolotto and the popular movements behind 
it constituted a threat to the state owned gaming companies Tipstjänst and Penninglotteriet, who traditionally controlled major parts of the gaming market in Sweden. Since 1997 these two institutions have merged into Svenska Spel, and together with other actors, such as state controlled ATG, recaptured their position on the market.

Figure 4. Audience Size and Ticket Sales 1991 through 2001. Average per Season

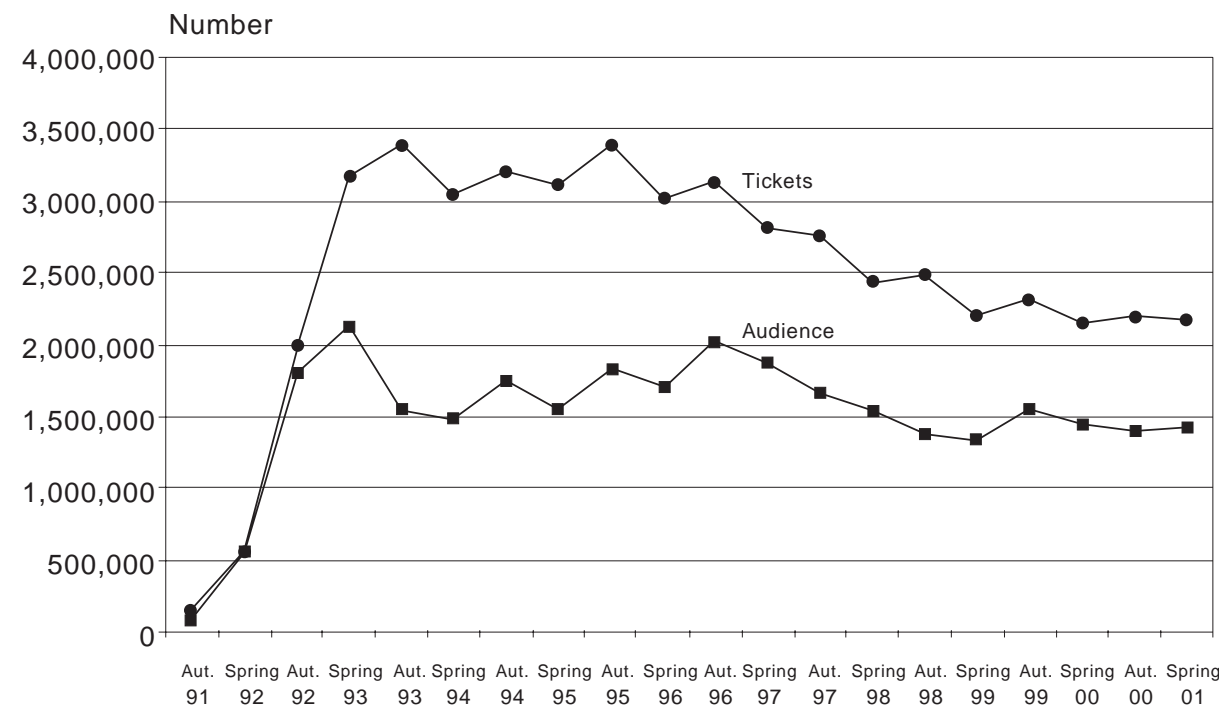

Since 1997 most statistics made around Bingolotto have pointed downwards, both when it comes to audience size and amount of sold tickets (Figure 4). That is, until the autumn of 1999, when changes were introduced in the programme. This season saw a renewed increase in audience size and ticket sales, although not at all close to the sales figures of 1993, 1996 and 1997. Since 1999, audience sizes have stabilised over the seasons, at the same time as turnover has increased due to the introduction of the 'double ticket' (see Figure 2). Svensk TV-Bingo's own estimations indicate an audience size of around 1.4 million viewers per show on average in 2000 and spring 2001. Although there has been a decrease in audience size (compared to the most successful years) as well as in ticket sales, there has been a continuation in the turnover, thanks to the introductions of new tickets, etc. On the other hand, the strategy adopted after the change has proven successful in attracting somewhat younger and more urban audiences (although the ages $45+$ still made up $76 \%$ of the audience in the autumn of 1999). The introduction of the 'double ticket' during the autumn season 2000, which increased the chances of winning but also costs twice as much (and gives twice as much in return to the associations that sell them), has proven successful and has broken the negative trend in the turnover statistics.

Besides the lottery turnover, millions of SEK have changed hands in the handling of prizes and sponsor benefits. The sponsors' parts in the handling of prizes in the programme have been the target of some muckraking in the press. Between 1990-1994, the local version of Bingolotto was convicted on several occasions by the authorities (The Swedish Broadcasting Commission's predecessor, Kabelnämnden) for violating the laws on advertising. The controversies around the production company IGS were repeated 
when the programme went national on TV4. As a consequence TV4, in its capacity as broadcasting institution, was eventually blamed, which in turn led to open conflicts between the channel's management and the producers of Bingolotto, primarily with Gert Eklund - a conflict that to a large extent took place in the evening tabloids.

To conclude, it is possible to characterise Bingolotto as 'more than a television programme', as is often held forth from within the production (and echoed in TV4's slogan 'more than a television channel'). It can also be concluded that a periodisation of the programme, to capture the historical trajectory, has to be made out of different premises: audience size, amount of lottery tickets sold, or size of turnover. The different parties involved in the programme's production and distribution have their focus on one or more of these. Sometimes their interests are mutual, and sometimes they are conflicting. Irrespective of which, the consequence is that they are interconnected and interdependent. How, in more detail, this complicated web of relations is constructed is the subject of the next section.

\section{The Interest in Bingolotto}

Following from the assertion that Bingolotto is 'more than a television programme' there are more interested parties involved compared with other game and entertainment television shows. All of these parties have opinions on the shape and character of the programme, its aesthetics and function, and on the handling of the lottery in relation to the television show. The kinds of agents involved in the production and distribution of a television programme vary, naturally, with the genre, the distributing channel's organisational and financial forms, prevailing laws and regulations, etc. Which agents are identified is also dependent on the vantage point, i.e. if one adopts the perspective of the television channel, of the production enterprise, etc. If seen from the perspective of the distributing channel, hybrid channels such as TV4 are foremost ascribed three interested parties: the political authorities, the channel (stock) owners, and the advertisers (Syvertsen 1996 p. 63). However, if seen from the perspective of the actual production of Bingolotto it is easy to see from the descriptions in the previous section that there are more parties involved.

On the organisational level, the interested parties are FSL, IGS and TV4. At an individual level these organisations are represented by Managing Director Leif Flatow of Svensk TV-Bingo, IGS' main owner Gert Eklund, Lars 'Sverre' Andersson (who was the main producer of the programme until the change), programme hosts Leif 'Loket' Olsson and Lasse Kronér, and TV4's Programme Director at the time, Jan Scherman, just to mention a few of those involved in the production and distribution of the show. All these agents naturally have an interest in having their say about the form and aesthetics of Bingolotto, and thereby actively contribute to the final product.

Besides those involved in the actual production and distribution of the programme, there are others who want to express opinions on the making of the show. Among these can be found the Swedish Broadcasting Commission (Granskningsnämnden för Radio och TV), advertisers and sponsors, local sports clubs and their members, the television viewers, and many more. There are, for example, several business activities, such as the small printer's office that prints the lottery tickets, that are connected to the programme indirectly and are thus dependent on its continuation.

These persons and organisations can be found at different levels within production and distribution, and their interests can be economic, political, cultural or social (or combi- 
nations of these). In relation to each of these kinds of interests, a range of questions on the internal relations between these organisations and individual agents evoke. And just as their interests in the production and distribution differ, they differ in a number of other ways.

Firstly, the products and commodities that result from their actions are of different kinds. The television programme in itself is of course one of these products, and so is the lottery. The production of the programme is also, at another level, part in the production of a television market, where formats and programmes are bought and sold. And in this same way the lottery, together with other games and lotteries, produces a gaming market from which gamblers can choose their favourite entertainment game. The production of the television and gaming markets are naturally not the primary aim of FSL, IGS and TV4, but rather a consequence of their actions. And, equally, it is not TV4 or FSL who alone have shaped these markets, and thus they could be said to re-produce, rather than produce, them.

Secondly, the values produced are of different kinds. The values can be seen as resulting from the different types of interests that govern the production, and accordingly they can be divided into economic, political, cultural and social values.

The different products, commodities and values are partly the result of goal-oriented, strategic action, and partly by-products of the main production. The values generated in the actual production and distribution of the programme can especially be said to arise as by-products. I will therefore in the following discuss the most obvious of these products, commodities and values.

An interested party of a television programme can be defined as an individual or collective agent who aspires to have influence over content, form, scheduling, or the like. Defined in this way, there are at least nine major interested parties:

- the Swedish popular movements, which, through FSL and Svensk TV-Bingo AB, run the lottery and thereby also formally order the production of the programme;

- IGS (from 2002 and onwards, Novamedia), who are commissioned by FSL to execute the task of producing the programme;

- television channel TV4, who distributes the programme;

- advertisers, who make it economically possible for parties involved to produce the programme;

- sponsors, who, just like advertisers, have economic interests in the activities;

- the Swedish state, which has an interest in regulating the media flows in Sweden, to control the lottery market, and also benefits economically from the gaming market through state-controlled lotteries;

- the competitors on the television market (mainly SVT, but also other commercial channels as well), for whom the success or failure of Bingolotto affects their ability to reach as many citizens as possible (SVT) or attract as large shares of advertiser's and sponsor's means as possible (the commercial channels);

- the competitors on the lottery and gaming market (Svenska Spel, ATG), who compete for the money of the gaming market;

- the viewers, who firstly make up the aggregate of individuals who, by their appearance in the form of audience statistics, function as a regulating instance that decides 
the willingness to buy advertising or sponsor time, secondly function as an imaginary audience against which aesthetic considerations are made, and thirdly, express actual views on the appearance of the show and the running of the lottery via letters to the editors, programme hosts, etc.

A short overview over the relations within the production and distribution of the lottery and the programme show the following: in order to secure the interest around the lottery draw for the lottery 'bingolotto', the Swedish popular movements order the production of Bingolotto, through their national interest organisation FSL, or Folkspel, which it eventually chooses as a name for its 'trademark', in the words of the managing director. FSL has in turn invented a special enterprise for this special production - Svensk TVBingo AB. Svensk TV-Bingo, however, does not have the equipment to produce television shows, and can be described as a mediator between FSL and the actual production company Gert Eklund Television (GETV), which is subsumed under the production enterprise Interactive Gaming Systems (IGS) in January 1999. IGS upholds the relation with the sponsors on the one hand, and with the distributing channel TV4 on the other. As a third relation, IGS also communicates with the approximately 30 'service stations' for the regional distribution of lottery tickets. These service stations distribute the tickets to the local sports clubs, or other associations whose members ultimately sell the tickets. TV4 has its contacts with the advertisers (through advertising intermediaries), who finance TV4 by buying advertising time between programmes. The precondition is that TV4 can offer the advertisers the target group that they want to reach. Thus there is an interest on the part of TV4 to create knowledge about the audience. There are also relations between TV4 and the Swedish state, through the Swedish Broadcasting Commission who look after the legislation on advertising (amount of time, placement of advertisements, etc.). There are also ties that bind the state and the organisations within the popular movements, as these parties in their capacity of being major gaming organisers are competitors on the gaming market, where the popular movements act through Bingolotto and other lotteries (which may or may not be connected with the media), and the Swedish state through ATG and Svenska Spel. The connection between the state and Bingolotto is also present via the National Gaming Board (Lotteriinspektionen), which regulates the lottery market.

The various positions taken by the interested parties result in different forms of power in the production process. There are those who have direct power over the form and content of the programme and the handling of the lottery, and those who have power of a more indirect kind. Among those with comparatively more power to influence the programme text are, for example, FSL and GETV/IGS. In a type of in-between position are TV4, advertisers, sponsors and the state. The most indirect power over the programme text and the form of the lottery is possessed by the audience. However, TV4 has - in contrast to the state (the Swedish Broadcasting Commission), advertisers and sponsors - the possibility to discuss the content of the programme with GETV, in policy questions via Programme Director Jan Scherman, and in more everyday matters via their executive producer. ${ }^{7}$ The different sponsors can naturally contribute to the aesthetics of Bingolotto by providing the producers of the programme with 'presentation clips' of their commodities. Presentation clips, as they are referred to among the production staff, are most often produced by GETV, although some sponsors such as Volvo present their commodities in clips with production values that obviously exceed what is normal for the show. To label the commodity-exposing clips 'presentation clips', instead of commercials, reflects the concerns taken towards the state and the regulations that state that TV4 
cannot broadcast advertisements within programmes. To contribute to the programme with video footage is of course to contribute to the content in a very obvious way. Other parties contribute to the forms and aesthetics in more subtle ways, such as avoiding matters that have to do with commodities that are competitive with sponsor products.

If sponsors sometimes directly contribute to the content of the show, this is less obvious for advertisers, not least since advertisers have their ties to TV4 rather than to the production enterprise GETV. Advertisers can thus be said to contribute to the creation of the context of the show, rather than to the show in itself. Furthermore, an interested party like the Swedish Broadcasting Commission can voice opinions on things that should not be included in the show (e.g., advertisements) - but only after the fact, thus setting the limits for what is legally acceptable. The power of the audience to influence the form and content of the show is even more indirect, and this interested party is taken into consideration mostly as a discursive category, as an ideal image to which the producers address their programme (cf. Gans 1957).

\section{The Popular Movements and FSL}

The main product that results from the activities of FSL (including its production enterprise Svensk TV-Bingo AB) is the lottery 'bingolotto'. FSL represent the popular movements, or, more precisely, the sports movement, as local sports organisations make up $90 \%$ of ticket sales. When discussing the Swedish 'popular movements' in relation to Bingolotto it is important to bear this in mind, although other parts of these movements are also involved in the handling of lottery tickets. The concept of the popular movements indicates a 'horizontal solidarity', which introduced 'new value systems and norms' when they rose from self-organisation in the 19th century. An important feature was that they 'gathered in protest for collective goals' of political, religious or moral kind. They are thus identified by their 'protest character' (Lundkvist 1977 pp. 55 and 226). Historically, the religious movement was the first to organise during the first half of the 19th century. Then followed the temperance movement, and towards the end of the century the workers movement. The sports movement that rose shortly after has, however, lacked the protest component, and is not always counted on par with the other movements.

FSL produces a lottery with the purpose of financing the organisational work of its member organisations and their basically idealistic activities. They thus have an economic interest in selling as many tickets as possible. Historically, lotteries have been a frequent component in the popular movements' economic activities, as well as one of the ways they have financed their activities besides state subsidies. Since its start in 1934, the gambling enterprise Tipstjänst (today, Svenska Spel) had exclusive rights to handling gambling tied to sports, and their revenues were to be of benefit to the state and the sports movement (Rönnberg et al. 1999 p. 20). Besides this connection to the state, the lottery activities also involve a binding to the state as regulatory authority.

The production of Bingolotto brings with it some of the values that dominate the popular movements and FSL. Although there are differences in ideals among the different popular movements, they also have a shared feeling for certain social, communifying values of togetherness, participation and collectivism. And since the sports movement is so dominating, there is a strong influence of physical fitness and spiritual health values. The value of collectivism can be attributed to the fact that many of the sports clubs actively engaged in the distribution of lottery tickets represent collective team sports, e.g. handball or football. The values created as a result of the part played by the popular 
movements are thus predominantly collectivist, and of social and cultural types rather than economic (since the economic activities do not aim at producing surplus value and profit for the organisations).

\section{Interactive Gaming Systems \& GE Television}

Interactive Gaming Systems (IGS) and its production company GETV produces, on behalf of FSL and Svensk TV-Bingo, a television programme as part of the lottery. The programme is produced both as a way of drawing attention to the lottery, and as a means of giving an account of the draw. In this perspective, the programme should be seen as a part of the lottery rather than the lottery as a part of the programme. IGS, as a commercial corporation, has the ultimate aim of producing surplus value for the shareholders. The profit is generated by the differences between production costs and sponsor revenues. As a consequence of the specific production culture around the programme (with its far-reaching connections to the popular movements, which can be attributed to many of the pioneers' background in sports activities), social and cultural values are produced. These values both result from, and can be analysed by, the specific audience address, the choices of artists and music, the aesthetics of the set design, etc. One might label these values or ideals as popular movement values, and they are in a wider sense involved in the production of 'popularity' (folklighet). As such, they play a part in the production of lifestyle ideals and values that also have a commercial potential (cf. Bakøy \& Syvertsen 2001 pp. 21ff).

These basically idealistic values are, paradoxically enough, combined with an ideology of consumption that is also obvious in the programme text, with its strong emphasis on the prizes in the form of consumer merchandise (food, cars, travel trips, etc.) (cf. Holbrook 1993). This ethos of consumption is reinforced by the commercials before and after the programme. It manifests itself in slogans such as 'Shop 'til you drop', which appeared as the headline of the web page that announced the coming events on Bingolotto on 8 September 2001. The overarching theme for that show was 'Shopping Saturday', and the audience was tempted with 'many amusing and wallet-friendly prices for the consumer-oriented (köpglade)'. ${ }^{8}$ Also generated are political values around environmental issues in the programme production, for example around 'Återvinsten', whereby used lottery tickets are returned by players/viewers and used in a special lottery draw, the economic surplus of which goes to funds for environmental issues (e.g., the WWF). This special lottery was subsequently renamed (or 're-branded', as the public relations jargon puts it) 'Miljövinsten' (the environmental draw), to strengthen the public relations value of taking responsibility for the environment. The importance of such values is highlighted when different competing interests clash, such as when attention was attracted to the fact that one of the prizes for Miljövinsten was a Volvo car. The re-labelling of this gaming segment can also be seen against the background of a harsh critique from well-known Swedish environmental debaters for giving profits of the game to unknown small organisations with dubious backgrounds, rather than to well established environmental organisations. ${ }^{9}$

\section{TV4}

TV4 functions as the distributor of the programme Bingolotto, and in this capacity the programme becomes a means for the commodity that it produces and sells on the market. This commodity is the audience, which it sells to advertisers (cf. Smythe 1977, Ang 
1991). ${ }^{10}$ In order to produce this commodity, TV4 arranges a schedule of programmes that aim to attract and gather those audiences that the advertising agencies, and their customers in different consumer markets (travels, cars, furniture, etc.), want to buy. To be more precise, it is the viewers' viewing time they buy (rather than the viewers themselves). TV4's interest is in reaching its target audience with commercials between the three different parts of Bingolotto. The composition of this target audience has changed slightly over the years. From the start, it was defined as those in the age span of 12-59 years (Annual Report 1996 p. 13). Beginning in the latter part of the 1990's, this was narrowed to the age span of 20-44 years, a group that according to then-managing director of the corporation, Thorbjörn Larsson, among other categories contains 'families with young children' (Annual Reports 1997 p. 5, and 1998 p. 3).

Through these arrangements, TV4 creates an audience with a specific gender, age, ethnicity, class and demographic composition, that can be priced and sold to those advertisers that have a demand for an audience with a matching composition. This is, however, not news to most of those who have studied media production from a political economy perspective, and such market logic has long prevailed in countries with a longer experience of commercial television than Sweden has. That 'broadcasters are selling eyeballs to advertisers' has also become widespread knowledge among people in the broadcasting industry itself (Andersen 1995 p. 5). This is also evident when speaking to audience analysts within TV4. Marketing strategies have been increasingly developed and made more effective, and it might be argued that they cut deeper into the production and affect the process in more fundamental ways than before. In this, Swedish broadcasters only follow trends laid out elsewhere in the world. They do so, however, under circumstances that are somewhat special to the Swedish (and Nordic) television market.

Thus, one specific feature stands out in the production of the audience in this specific national context. The legislation and restrictions for advertising and commercials in Sweden have made TV4 develop new methods to make the handling of the audience commodity even more effective. These new methods are labelled DIRR, which stands for 'differentiated regional advertising', and RBS, which is short for 'run by station'

Sweden is a country that stretches out for 1,574 kilometres from north to south. This means that there are many regional differences between the most southern and the most northern areas. Since 1997, TV4 has thus divided the nation into 16 regions, all of which can be separated and individually targeted with advertisements. Theoretically, this means that the overall programming consists of 16 different schedules. This strategy of programming is, however, for obvious reasons not employed to its full extent. It means, however, that TV4 can broadcast advertisements to regional markets. This refinement of the channel's advertising strategies has a number of consequences. Firstly, it makes it possible for advertisers who would never have been able to afford to broadcast over national television (since their potential customers are found only locally or regionally) to take advantage of the commercial possibilities of television. Secondly, it makes it possible to regionally adjust advertisements with national potential in time to suit regional markets. Since Sweden's outstretched geographical character means that winter arrives several months earlier in the north than it does far south, a commercial clip for, say, winter tires can be aired in October in the most northern parts, when there are still a couple of months before winter tires can - and according to Swedish legislation are allowed to - be used in the far south. Since a programme such as Bingolotto has such a long season, this advertising strategy fits like a glove for advertisers. From this follows that the audience commodity is not only structured by age, ethnicity, gender, educational 
level or settlement (large city, town, village, countryside), but also in which city, town, village or part of the countryside the audience segment can be found.

Another market strategy, introduced in 1998, is RBS. This means that the advertiser buys a certain amount of 'contacts' in the target group, e.g. a specific amount of young, 20 -year-old women living in large cities. TV4 then places the commercial close to, most often before, the television show (film, news broadcast, entertainment show) that attracts this very segment. And when the commercial has reached the audience size agreed upon with the advertiser, the deal is closed. In order to be cost-effective, TV4 obviously places the commercials as close as possible to those shows that attract the 'right' audience, in order to maximise audience reach with as few transmissions as possible of every commercial clip. This naturally sets new demands for sophisticated instruments that can measure the audience for every single commercial, and accordingly increasingly more effective ways of controlling the audience commodity this way have been developed. If the broadcaster is effective, it can reach the audience segments in few screenings, and thus take on more advertisements, for other commodities that advertisers want to promote, and in the end produce more surplus value for their shareholders. This strategy can be seen against the fact that the time for commercials that TV4 has at its disposal is restricted by its license agreement with the state. The agreement contains two important restrictions. Firstly, TV4 cannot interrupt programmes with commercials, but must screen them between programmes. This is, of course, why shorter programmes are preferred by the channel to lengthier ones, and a reason why it also produces programmes in different parts (such as the three parts of Bingolotto). ${ }^{11}$ Secondly, TV4 cannot exceed a certain time limit with commercials. One way to circumvent this restriction is to develop more effective ways to use the time at their disposal, hence RBS.

This can be compared to the 'old' ways of handling commercials, where an advertiser buys airtime in connection to the shows that the advertiser, based on audience measuring, thinks is reaching the right audience; this strategy is labelled 'specific'. Obviously, such strategies are not specifically effective, if one takes Bingolotto as an example. Since the audience size for the show is quite large, and since the price of commercials depends on audience size, it is quite expensive to have a commercial in the break before the programme. This also means that there will be a certain amount of viewers in the audience that do not belong to the target group - those audiences that become 'waste', in the jargon dictated by commercial logic. Usually it is said that commercial television is concerned with reaching as large an audience as possible. This is often far from true, and sometimes large audiences can be negative, if seen from a commercial point of view, as they contain too much 'waste' that the audience buyer has to pay for, but has no use for. This is also the way in which many sponsors argue, according to the marketing manager at IGS. He thus sometimes finds it hard to convince sponsors that they might persuade people outside of the target groups to buy the products exposed in the programme, and he has several 'happy stories' that exemplify how previous sponsors have discovered new customers accidentally this way. This is, of course, a rhetoric that has developed to convince sponsors to 'take part in the concept'.

That TV4 can reach their target audiences across the country, compared to their commercial competitors who broadcast via satellite and thus can only reach those with cable or satellite dishes, means that it can employ the DIRR and RBS strategies in a more effective way. This also reveals how the market logic dictates the way in which programming is made. As the driving force of the capitalistic market system is to produce surplus value, there is a continuous need to increase this value. 'Staying put is the same thing 
as taking a step backward', as then-Managing Director Thorbjörn Larsson claimed in TV4's Annual Report for 1998.

The goal-oriented activities of TV4 result in (economic) surplus value, which is turned into profit for the shareholders of the broadcasting company, and this is what the managing director always emphasises in the annual reports. However, there are other values produced in the process that TV4 benefits from. In producing a certain type of audience for the programme Bingolotto, public service values are also produced, which are pointed to in statements by the managers of the company. Former Programme Director Jan Scherman often calls upon such values in relation to the show:

The programme exemplifies many of the values that I find important for TV4 to represent in its capacity of being a commercial television broadcaster. For me it is extremely important to mark a pronounced distance from TV3, TV5 and their form of unrestrained and cynical commercialism in their programming. On the other hand we don't want to be associated with the programming profile of Sveriges Television either. It is somewhere in between these positions that we want to place ourselves, and thus Bingolotto fits just into that publicist profile of ours. [...] Previously, I used to speak about 'commercially financed public service' in relation to our profile, but we have lately begun to speak about a 'quality commercial channel', but one that has a genuinely popular anchorage, and that's where Bingolotto fits in. I find that the definition of public service that you find in official reports from the state applies well with the programme. The programme is beneficial to society at many levels, both as broadcast programme and in the wider society. And it is a kind of entertainment that I find... sympathetic is a word I often use when describing Bingolotto. It doesn't expose people in unpleasant ways, doesn't devote itself to 'mobbing journalism', but is... well, sympathetic. (Interview with Jan Scherman 1 February 2000)

In his argument, Scherman emphasises the utility aspect of the programme and the public service ideology to which this refers. This argument is obviously not directed towards those with economic interests in the programme (e.g., the advertisers who finance the activities and are the basis for the possible profits for TV4), but rather points to the obligations that the broadcaster must attend to according to the license agreement. Former Programme Director Scherman can find support in his argument from statements by the former programme host Leif Olsson, who, with his motto 'everybody can take part' ('alla kan vara med'), has aligned himself with those obligations that say that the broadcaster should address the whole population in Sweden (not just groups with great purchasing power). This is not least exemplified by the fact that Olsson, in his farewell programme before he resigned in June 1999, was officially thanked for his services by the Prime Minister of Sweden, Göran Person. A programme such as Bingolotto thus supplies TV4 with legitimating arguments towards both the economic and the political power field, and it is hard to find a more obvious confirmation of the political legitimacy of TV4 and their programming policies than this (cf. Bolin 2002).

\section{Other Interested Parties}

A fourth interested party is advertisers. Advertisers promote commodities by exposing them to the viewers and lottery players. The commodities exposed are both material goods (cars, coffee, furniture, clothing, food, etc.), services (travels, weekend dinners, etc.), and symbolic merchandise (cash, share portfolios, etc.). Advertisers thus mediate 
between producers of material and symbolic goods and services, and the broadcaster TV4, who delivers audiences to be exposed to the merchandise. Advertisers buy viewing time from TV4 and deliver this time to producers of goods and services, thus themselves producing a service that they sell to their customers.

Sponsors, on the other hand, can either work through advertising agencies that mediate between them and the production company IGS (and subsequently Novamedia), or make direct contact with the marketing division of the company. In the first case their relations are similar to those of advertisers, but in the second their more direct relations result in a different position when it comes to influencing the show's aesthetics.

Advertisers and sponsors ultimately produce a consumer market (together with other sponsors and advertisers who promote other commodities). The power to influence the aesthetics of the programme differs among the various advertisers and sponsors. Some have quite direct influence by, e.g., contributing with their own commercials - as one of the main sponsors, Volvo, does in its clips, which clearly have much higher budgets than do those produced by IGS. Others have a more indirect influence, whereby the kind and quality of the commodity to be exposed is taken into consideration by the production staff in 'presentation clips', etc. This can, for example, result in the formation of certain themes within the show (around travel, for example). In both cases the overall focus on commodities contributes to the production of an ideology of consumption, as well as a promotion of certain lifestyles constructed in consumption (cf. Bjurström 1991, Campbell 1987, Jansson 2001). The outcome of the production in this case is naturally economic profit (surplus value) for the advertisers, sponsors and the production company, but cultural lifestyle values are also produced around the consumer merchandise. The production of lifestyle values is directly promoted by the lifestyle analyses of the audience carried out by audience analysts such as ACNielsen in the form of 'Minerva lifestyle segmentation'. These segmentation analyses, and similar analyses such as Orvesto, focus on patterns of consumption among the viewers, whereby consumption of certain lifestyle commodities is correlated to consumption of other commodities and services. In this process, it could be argued that the lifestyles in themselves become commodities that are sold to advertisers and sponsors.

Another interested party, although not primarily economically, is the Swedish State administration. The state acts through the Swedish Broadcasting Commission and The National Gaming Board and does not produce commodities. However, its acting through its legal and other bodies produces political and cultural values as a consequence of the argumentation that precedes decisions.

The seventh and eighth interested parties are the competitors of Bingolotto as a television programme and as a lottery. Competition is naturally a crucial market component. An example of competitive activities on the television market is 'counter-programming', i.e. competitors compete for viewer attention by challenging their rivals and by scheduling a similar programme 'head to head' in a specific slot (cf. Ellis 2000 pp. 130ff). The viewers are the raw material that TV4 as a producer works up and refines to the audience commodity that it then offers to advertisers, by giving it an outer form shaped by a certain age, gender, education, etc., which in turn determines its economic value on the advertising market. As all commercial broadcasters compete in the same advertising market, they need to get the attention of the same segments of the audience that are in demand from advertisers and sponsors, which is why the market logic leads to programme politics that privilege similar programmes. 
Seen from the perspective of the advertising market it would seem as if the main competitors of TV4 should be its rival commercial channels TV3 and Kanal 5. Interesting in this context, however, is that TV4's main competitor seems to be the public service broadcaster SVT and its two channels SVT1 and SVT2. For many years it seemed as if SVT did not wish to, or could not, compete with Bingolotto, a fact that comes as no surprise since SVT actually does not have to compete for viewer attention since it is not financed with commercial advertising (although it receives minor revenues from sponsors) (cf. Björkegren 2001 p. 146). However, with the introduction of Expedition: Robinson in 1998 SVT took on the challenge from TV4. That TV4 regards SVT as its main competitor is by no means surprising. The public service broadcaster has a long history in the minds of Swedish viewers, and has accustomed them to certain kinds of entertainment, especially on Saturdays, for example the earlier-mentioned Hylands hörna and other popular family shows. Comparisons with this milestone in Swedish television history are made by both Gert Eklund, the 'creator' of Bingolotto, and TV4's Programme Director Jan Scherman in our interviews, and in Annual Reports (e.g., the Annual Report of 1999 p. 16). And by making such comparisons they reveal some of the hopes and ambitions that they have for Bingolotto. Eklund's competitive ambitions aside, it is interesting to see the argumentation from Scherman as a representative of TV4. In our interview he comments on the programming strategies of SVT:

I read the other day that SVT's new programme director Micke Olsson had stated that 'Bingolotto is not public service, it could never be broadcast by Sveriges Television [SVT]'. Then I read an interview with my predecessor [as programme director] Lars Weiss, who in the journal Vision [branch journal for television professionals] has also paid attention to this statement, where he said that it is quite remarkable that Expedition: Robinson would be a public service programme but not Bingolotto. (Interview with Jan Scherman 1 February 2000)

One explanation for this competitive relationship can be found in the struggle for the value of 'being public service'. As a hybrid channel (cf. Søndergaard 2000), TV4 has to adjust to certain obligations that follow from the licence agreement with the state. Some of these obligations are of public service character, e.g. having a certain amount of local production, reaching all parts of the country and all kinds of audiences, etc. And due to these obligations, TV4 has for many years struggled to legitimate its activities by holding on to these public service values, which has led to a continuous reproduction of the values. Thus a competitive situation was established, in which the stakes concern 'who is the most public service' (Syvertsen 1990) - a competition that generates both cultural and political values.

As a competitor in the lottery market, Bingolotto competes for the money of the gaming audience. As the other large games in Sweden are run by companies with close ties to the state system, the state as an interested party is involved also here, as are the ideal organisations within the popular movements. Generated here also are cultural values, mainly through the activities of the ideal organisations.

Last but certainly not least among the interested parties, we find the people who watch the programme (and play the lottery). In discussing viewer activities, one might be tempted to use the marketing term audience (cf. Mosco \& Kaye 2001). However, it is imperative to distinguish between the audience as a commodity and the viewers as the social subjects that produce meaning, identities, and culture. The audience is a statistical construction based on aggregated characteristics among individuals (Ang 1991 pp. 
53ff; cf. Abercrombie \& Longhurst 1998), packed by the audience analysis industry represented by MMS and ACNielsen. The audience cannot act; it has no will of its own. The audience is incapable of producing anything, and as a statistical aggregate it is acted upon. However, as viewers and lottery ticket buyers these viewer subjects are actors who choose if they will buy tickets and how many to buy, as well as whether or not they are going to watch Bingolotto. The viewers naturally produce several things while watching: meanings, social relations, and sometimes - as is the case with the viewers of Bingolotto - fan material that they send to the programme production staff in the form of mascots and other small tokens of appreciation. The immensely popular Leif 'Loket' Olsson had a steady flow of such things coming to the studio in Gothenburg, and these items were exhibited in glass showcases at the entrance of the studio, for arriving guests of the program to see. These guests make up the third category in addition to the audience and the viewers. They are mostly regular viewers of the television show that come from various parts of the country, often in groups that have been organised by local sports clubs or other associations within the popular movements. However, once they enter the studio they take part in the production of the program, and in that capacity they are expected to act with cheers and applause, disappointed sighs and 'bingo!' shouts. Thus, they have an important function for the programme text, in which they act as an instance of identification for the television viewers and as representatives of those sitting in front of their television sets in households across Sweden. In this function the guests in the studio, together with the viewers at home, construct and produce social and cultural values in the act of communification in which they are involved (cf. Bolin 2000 p. 63).

However, this symbolic product in the form of social values built around identification and identities can hardly count as a commodity. A cultural identity cannot be sold on a market, and the experience of the show cannot be traded for another experience or for money. In an interesting discussion, Sut Jhally \& Bill Livant (1986) argue that viewers work for the television networks when watching, as they take part in the production of viewers' watching time together with the networks. Their work for the networks produces 'surplus watching-time' (p. 127). In exchange the viewers get 'program content', e.g. entertainment shows such as Bingolotto. Although it is certainly true that the networks need people who watch the programmes they broadcast, and that the viewing time is refined by statistical measures and sold to advertisers, the metaphor of working has a 'blindspot', to paraphrase Dallas Smythe (1977). If audiences are working, and if their salary is entertainment shows, how can they further convert this salary? You cannot buy food for the experience you have earned in watching Bingolotto or any other show. And few people besides media researchers can convert the knowledge gained from such shows into exchangeable commodities. It is then easier from the perspective of Jhally \& Livant, and with the terminology of Marx (1867/1974) in his first chapter of volume one of Capital, to claim that the watching of entertainment is part of the recreation of the worker's labour power. This recreation time is then refined, packed and sold on a market. In this perspective the watching is certainly part of the market system, although not as an activity that produces something but as raw material for refinement in the production process by others (cf. Meehan 2000 p. 77).

\section{Relations Between Interested Parties}

The interests of the different interested parties occasionally coincide, but there are also some interests that conflict. This is most notable when economic interests collide. IGS/ Novamedia and TV4, for example, have quite different interests from FSL. This conflict 
of interests stems from the ideal associations' interest in the lottery turnover on the one hand, and the interests in audience ratings that the commercial actors share, which are dictated by their dependence on advertisers and sponsors, on the other hand. This conflict can be illustrated by IGS' and TV4's outspoken will to change the aesthetics and content of the programme towards the end of former host Leif Olsson's career in the show, a change that aimed to attract younger and more urban audiences with greater purchasing power. As can be seen in Figure 1 above, audience ratings decreased substantially between spring 1997 and spring 1999. At the same time, the age structure of the audience became older. There was an increase among viewers that were older than 60 years, and a decrease among those between 15 and 44 years. The latter age segment is precisely those who are the primary target group for TV4, and it is against this background that it wished to change the audience address. The strategy was partly successful for IGS and TV4.

The conflict between the management of IGS and TV4 on the one hand, and the popular movements and FSL on the other, took on personal proportions in Leif Olsson's last show. At the end of the programme the resigning Olsson was thanked for his services by Managing Director Gert Eklund (IGS) and Programme Director Jan Scherman (TV4). Olsson, who in several interviews had declared that he wanted to make a programme for the elderly and those with less urban identification, received thanks from Eklund and Scherman quite reluctantly. After having received flowers and thanks (and a telegram from the Prime Minister), he addressed the viewers, with his eyes straightforward into the camera, pleading for a continuation of the style of the programme:

Thank you very much! A great many viewers around Sweden have become best friends with me over the years. I know that many are grieved. But, all things have their end, and now eight years have passed... And now I will try to do something else. And I will not do anything in television, you need not worry about that. 'Cause if I did, I would still be in Bingolotto. So, now Lasse Kronér will take over from the 28th. And shouldn't he get the chance?! And I will just leave one message to Lasse and the rest: take care and preserve Bingolotto in the shape it has today! There are going to be some changes, that I am fully aware of. But be very careful, so that we can take care of those people that really need Bingolotto more than others.

The subsequent changes concerned, among other things, the performing artists. With Olsson as host, dance orchestras set their mark on the show, and contributed to the low status of the show among urban youth and people with higher education. However, the dance orchestras were an important feature to many viewers, according to studies conducted by TV4. When Lasse Kronér began hosting the show a more varied mix of artists was introduced, supposedly appealing to younger audiences. Among the international stars that have appeared on the show since then are Ricky Martin, David Bowie, Kim Wilde, and others who have a following of young adults (rather than teenagers).

The change of host also meant that a new style of hosting was introduced. Kronér, just like Olsson, has a prominent dialect that reveals his firm rootedness in Gothenburg. However, 'Loket' has a background as a handball referee and fifteen years' experience of hosting morning radio shows. Kronér, being some twenty years younger, and with a background as an entertainer in the song and dance group Triple'n Touch, has a more international or US-inspired way of hosting. A telling difference is that Olsson always played the bingo games sitting on a living room sofa together with three guests that had 
been drawn from among ticket buyers the previous week. Kronér stands at a podium or walks about on the stage during the bingo games, thus distancing himself from the players (and thus symbolically from the viewers). The symbolic social and cultural community that resulted from Olsson's way of acting, as well as his unprecedented knowledge about Swedish geography, seemingly knowing every minor locality in Sweden, has changed substantially. In addition to this, the set design has changed in that the former air of 1950's Swedish 'People's home' (folkhem) has disappeared.

As can be seen from Figure 4 above, these changes have not led to any increase in ticket sales, which ought to have caused concern for FSL. As a matter of fact, there has been a decrease in sales figures. This has been economically compensated for by an increase in turnover, made possible by the introduction of new 'double' tickets and special lotteries such as the Millennium Lottery on New Year's Eve 1999 (which in itself had a turnover of 236 million SEK). The economic values have been preserved through these measures, while the social values that have bound individuals together in a lottery playing community have diminished. Thus, there has been no corresponding compensation for the loss of the social values that results from the fact that increasingly fewer people are involved in the lottery handling process, both as distributors of tickets and as players.

The various agents involved seem to have succeeded in their mutual efforts to reach a sufficient level of income from lottery sales (for FSL), and to capture the target audiences that IGS and TV4 need to reach in order to deliver audiences to sponsors (on the part of IGS) and advertisers (on the part of TV4). However, there are other conflicting interests, for example among TV4, IGS, advertisers and sponsors, that are revealed in interviews of the managerial staff. For example, it has not been popular among the sponsors that have made agreements with IGS when competing brands have bought advertising time around Bingolotto from TV4. Within the program, sponsors have branch exclusivity, but IGS cannot guarantee that competing brands will not buy advertising time from TV4.

To summarise, one could say that the different interested parties can be divided into four types. Firstly, there are those within the administrative-political system. These make up the minor part of the parties (The Swedish Broadcasting Commission, the National Gaming Board, and the competitors on the lottery market). Secondly, there are those that can be found within the market system, which comprise most of the parties (IGS/Novamedia, advertisers, sponsors, TV4, and the other competitors on the television market). Thirdly, there are those that can be found within the cultural public sphere (cf. Mortensen 1977). These are FSL and the associations that distribute and sell tickets. Then there are those within the private or intimate sphere - the viewers at home.

Conflicts that arise are predominantly between spheres, and most conflicts appear between the first three of these four. However, although the agents within the market system strive towards similar goals, competitive characteristics of the market also provide for some system-internal conflicts. Thus, there are also competing interests within the various collective bodies, as is shown by the example of branch exclusivity above.

\section{Internal Differences within Interested Parties}

The overarching aims with each activity - the production of the lottery for FSL, the production of the programme for IGS/Novamedia, the production of the audience for TV4 - are probably not controversial among individuals in these three organisations. However, there are obvious differences among the various individuals about secondary aims, i.e. goals that can be connected to the production of symbolic values. In this section I will 
point to some such divergences, and how they affect the products and commodities produced.

When Bingolotto was first introduced on cable television in the Gothenburg area, many of those involved had little or no experience in professional television production. Many came from the sports movement. At the start of the deregulation of the Swedish television market, there were opportunities for non-media people lacking experience in media production to enter the production field, a fact that was also true in other Nordic countries at the time. In Norway the dating programme Reisesjekken started in the same way, supported by enthusiastic 'amateurs' with surprisingly low budgets and a good portion of entrepreneurial spirit (Bakøy \& Syvertsen 2001 pp. 23ff). Another feature that this Norwegian production shares with its Swedish counterpart is its rebellious attitude towards the authorities, and towards the 'old' television system. The Norwegians also started with inexperienced production staff, as well as with little commercial competition on the television market, a fact that should not be neglected. Denmark had its syndicated version of Wheel of Fortune - Lykkehjulet - as a prominent feature in the deregulation process when Danish TV2 started in 1988 (cf. Skovmand 1992 p. 92). Put in the words of Kevin Robins \& James Cornford (1992 p. 197), who noticed the same phenomenon in the UK some years earlier, these 'Trojan horses' enabled 'non-television media groups to penetrate into the broadcasting sector'.

Many of those who were part of the production team of Bingolotto early on had a background in the sports movement and in ideal associations. There was a deeply rooted solidarity among the staff concerning the rhetoric behind the program, by which FSL promoted the programme as being 'best friends with sports clubs', as a 1999 slogan read. There was also a marked distance towards those who supposedly did not share this conviction, for example those who worked with media production in Stockholm, and the advertising business and economists in general. ${ }^{12}$ Clashes between individual representatives for economic and cultural ideals can be exemplified in the actions taken by the acting managing director for IGS in 1999 (then under the name Eklundgruppen). He was genuinely loathed by most in the production team, as well as others who worked close to the team, such as those responsible for the distribution of lottery tickets in the Gothenburg area whose office was next to the studio. Just as described by Jeremy Tunstall (1993 pp. 152f) in relation to television producers, the staff considered the managing director one of those 'wankers in suits' that represent an economic and administrative rationality that are a poor fit with the cultural rationality represented by those with a background in the sports movement (cf. Björkegren 1996). After several incidents with the staff, he resigned during the summer, just during the process of change for the programme.

Internal discrepancies also concern divergent aesthetic opinions on what is 'good television'. Here, the production process around Bingolotto provides us with examples on the professionalisation process, in which there is a continuous adaptation to television standards of other programmes. This is revealed in interviews with the editing staff, where the main editor was clearly ashamed when confronted in an interview with his first work on the programme. And it comes as no surprise that the programme looks quite different when one compares a broadcast from 1991, with few cameras, a studio room otherwise used as a lunch restaurant, and poor lighting, with broadcasts of later dates, where the colour scheme and lighting have become increasingly similar to Who wants to be a millionaire?, which was eventually broadcast by TV4 as well.

The internal discrepancies reveal how certain values tend to be dominating at times. Not surprisingly for a commercial production, economic values tend to dominate in the 
end: 'When values struggle with dollars, put your cash on the cash every time' (Tetzlaff 1992 p. 22). The struggles between values, however, do work at several levels. At the organisational level they work between the different systems and spheres described above. This should be of no surprise, but the interesting thing is how and on which occasion economic values tend to permeate and intrude into spheres dominated by other values, and in which situations, however few they may seem, that economic values are repressed. A revealing example can be related to the fact, mentioned earlier in this article, that historical periodisation of the programme must be made from different perspectives. Depending on which perspective one chooses, one finds different peak moments in the programme's history. For example, the managing director for FSL, Leif Flatow, who is chief representative for the popular, ideal values, and responsible for securing the interests of the popular movements, describes in our interview Bingolotto's golden age as being between 1994 and 1996. If one relates this to the development of ticket sales and turnover in Figure 3 above, it reveals that the ideal engagement and the large lottery sales exceed this period. Already in spring 1993, the amount of sold tickets was at its height. But the increase in turnover does not rise dramatically until 1994, and it is this turnover that seems to be of value for Flatow. It is quite clear that it is the economic, rather than the social value of having many people engaged in the distribution and handling of lottery tickets, that he espouses and has an interest in. In this, the economic rationale forces out those social values connected to the handling of lottery tickets (where the golden age would be assigned to another period).

\section{Interplay Between Values in the Post-Public Service Era}

Bingolotto is a programme that works in a new, post-public service Nordic media geography, marked by the logic of commercial television and its goal of maximum surplus value, as in other kinds of capitalist commodity production. However, the historical context of the production of the programme, in the wake of the deregulation of the broadcast media in the Nordic countries, makes the programme generate several other values besides the economic ones. To reduce Bingolotto to a commercial moneymaking machine is therefore to miss out entirely on some of the explanations that lie behind the contemporary workings of the culture industries. The somewhat overly complex production of Bingolotto might be extreme, but the kinds of relationships that the production of the programme highlights also make it a perfect prism for analyses of modern, commercial enterprises, and how ideological workings permeate our everyday electronic surroundings. The commodity form is obviously central to this mode of production. It is, however, certainly not pure economic logic that makes the system tick, and the importance of other values that add to, reinforce, and sometimes obscure, the economic intent that much media production has as its raison d'être should not be underestimated. This might illustrate the late modern form of commodity fetishism, to use Marx's (1867/1974) terminology, wherein the economic value becomes embedded in other values.

In the production process, not all things produced take on commodity form, and a too one-sided concentration on the production of surplus value and profits can even be of hindrance in the long run. In order to be bestowed with use value, every commodity must mean something to someone, i.e. be equipped with cultural values. Through this process its exchange value is formed, and it can be circulated on a market. Cultural values are thus of utmost importance to the market system. Political and social values are not equally obvious in their ability to contribute to the exchange value of commodities. However, under certain circumstances and in specific combinations even these values can 
be beneficial to the use value, as well as to the exchange value. The opposite is, however, not true. Social values alone cannot be sold on a market. If the social value of togetherness should be granted exchange value (and not just use value), it must be connected with something else.

Capitalist production in general is saturated with examples of paradoxes, and so is commercial media production. Not least paradoxical is the fact that Gert Eklund, after having been engaged in one of the largest Swedish media production projects for more than a decade, still seems to consider himself a challenger within the field of television production, and a representative of an alternative form of television. At the same time, Bingolotto espouses and reproduces some of the more fundamental values of public service television in the form of social, cultural and political values (if also mixed with the economic values of commercial production). This is possibly one of the explanations of the success of Bingolotto, and one of the reasons why TV4 has been so successful in attracting both those who reject traditional public service programming, as well as those who adhere to the habits of the public service output.

Morris Holbrook (1993 p. 115) ends his book on US television game shows by rhetorically asking why he finds himself 'helplessly grinning' and 'rejoicing in my feelings of shared triumph' while watching game shows, in spite of the fact that they 'reflect a capitalist ethic of materialism based on greed' that exemplifies 'the culture of consumption gone berserk', and as such should be opposed. The answer to this question is that these shows also reflect other values, which are less negative in most people's eyes, and can sometimes overshadow the most apparent profit motifs behind commercial activities and make programmes enjoyable even to those who would otherwise object to the consumer ethic displayed.

\section{Notes}

1. In this article I will restrict my discussion to television production. The introduction of commercial enterprises have naturally also affected radio production, but as the examples are drawn from a project on television programming I will leave aside the discussion of radio.

2. Sweden is a country with a long tradition of organised social, or popular movements, for example the workers' movement, the temperance movement, and the sports movement. These can be considered 'the institutionalised lifeworld', in Jean Cohen \& Andrew Arato's (1992) labelling (cf. Dahlgren 1995 pp. 127ff), and a part of the public domain or the public sphere in the theoretical following of Jürgen Habermas (1962/1989).

The Swedish popular movements, particularly the sports movement, but also parts of the temperance movement, pensioner associations, societies for disabled, etc., have a long-standing tradition of financing their (non-profit) activities through different kinds of lotteries. They also have an organisation that administrates the lotteries involved on a national level: FSL (Folkrörelsernas Samarbetsorgan i Lotterifrågor, which roughly translates as The Popular Movements' Lottery Cooperation).

3. The concept was sold to the Dutch production enterprise Novamedia in April 2001. Novamedia took over in spring 2002, and changes after this takeover have thus not been considered here.

4. "Eklund säljer sitt Bingolotto - men får behålla de internationella rättigheterna för tv-succén", in Göteborgs Posten 10 April 2001.

5. Audience ratings are taken from MMS between 1991 and 1994. From 1995 onwards, the ratings are based on statistics from Svensk TV-Bingo. These are estimated on the grounds of the highest value reached every Saturday. Thus, these figures depart somewhat from those from MMS, who counts all three parts of the program separately. As a consequence the ratings accounted for by Svensk TV-Bingo are slightly higher. If compared, the ratings from MMS show between 10-30,000 viewers less than do those from Svensk TV-Bingo. For the purpose of this article, and the overall tendencies accounted for, this is of minor significance. 
6. As we have had no access to ratings for each program before 1995, we cannot make any comparisons before this date. However, nothing indicates that the pattern has differed dramatically before.

7. Leif 'Loket' Olsson and Jan Scherman have, on occasions, had public discussions in the press on the character of the program, in which Olsson has argued for the maintenance of the program style and audience address. Scherman has instead pointed to the need for change in order to reach broader audience segments. The executive producer did not have much to do with the actual production or distribution of the program, since the links between the studio in Gothenburg and the television channel headquarters in Stockholm were primarily a question of transmission technology, and were thus entrusted to the technical staff at TV4. In our interviews with her, it was obvious that she rarely watched the show for which she was executive producer.

8. (http://tv4.se/default.asp?nav=6\&innehall=http://content.bingolotto.se/,010908). After the taking over of the format to Novamedia, the web address has moved to the web pages of TV4 (http://tv4.se).

9. 'Björn Gillbergs attack mot Bingolotto', in Aftonbladet 25 September 1996.

10. TV4 naturally rather want to make it seem as if the viewers are the customers of the channel, as Programme Director Jan Scherman claims in the headline 'The viewers - our customers' in the Annual Report of 1997 (p. 9).

11. This has, however, changed recently, and since April 2002 it has been possible to interrupt programs longer than 45 minutes ('TV4 får friare reklamregler', in Dagens Nyheter 10 February 2002).

12. Independent production of television in Sweden is highly concentrated to Stockholm, and IGS/Novamedia are an exception to this rule.

\section{References}

Adorno, Theodore W. \& Max Horkheimer (1947/1979) Dialectic of Enlightenment. London: Verso.

Abercrombie, Nicholas \& Brian Longhurst (1998) Audiences. A Sociological Theory of Performance and Imagination. London: Sage.

Andersen. Robin (1995) Consumer Culture and TV Programming. Boulder, Co: Westview Press.

Ang, Ien (1991) Desperately Seeking the Audience. London: Routledge.

Bakøy, Eva \& Trine Syvertsen (eds) (2001) Sjekking på TV. Offentlig ydmykelse eller bare en lek. En studie av Reisesjekken - programformat, delttakere, produsenter, sponsorer og publikum. Oslo: Unipub.

Bjurström, Erling (1991) Livsstilsreklam. Stockholm: Konsumentverket.

Bjurström, Erling (1993) Spelar rocken någon roll? Kulturell reproduktion och ungdomars musiksmak. Stockholm: Statens ungdomsråd.

Björkegren, Dag (1996) The Culture Business. Management Strategies for the Arts-Related Business. London \& New York: Routledge.

Björkegren, Dag (2001) Glädjens mekanismer. Sveriges Television. Stockholm: Carlssons.

Björkemarken, Mariann (2000) Öppna kanalen i Göteborg. Utvecklingen av en lokal TV-verksamhet. Göteborg: Öppna kanalen.

Bolin, Göran (2002) 'Public service är bara två ord. TV-produktion med maktrelation', in Espen Ytreberg \& Staffan Ericson (eds) TV mellan hög och låg kultur. Kristiansand: Høgskoleforlaget, pp. 89-97.

Bolin, Göran \& Michael Forsman (2002) Bingolotto: produktion, text, reception. (Mediestudier vid Södertörns högskola 2002:1) Flemingsberg: MKV.

Campbell, Colin (1987) The Romantic Ethic and the Spirit of Modern Consumerism. Oxford \& Cambridge, MA: Basil Blackwell.

Cohen, Jean J. \& Andrew Arato (1992) Civil Society and Political Theory. London: MIT Press.

Curran, James (ed.) (2000) Media Organisations in Society. Oxford: Arnold.

Dahlgren, Peter (1995) Television and the Public Sphere: Citizenship, Democracy and the Media. London: Sage.

Ellis, John (2000) Seeing Things. Television in the Age of Uncertainty. London \& New York: I.B. Tauris.

Gans, Herbert (1957) 'The Creator-Audience Relationship in the Mass Media: An Analysis of Movie Making', in Bernard Rosenberg \& David Manning White (eds) Mass Culture: The Popular Arts in America. New York: The Free Press, pp. 315-324.

Habermas, Jürgen (1962/1989) The Structural Transformation of the Public Sphere: An Inquiry into a Category of Bourgeois Society. Cambridge, MA: MIT Press.

Holbrook, Morris B. (1993) Daytime Television Gameshows and the Celebration of Merchandise: The Price is Right. Bowling Green: Bowling Green State University Popular Press. 
Hultén, Olof (1996) 'Public service och den mediepolitiska utvecklingen i Norden', in Olof Hultén, Henrik Søndergaard \& Ulla Carlsson (eds) (1996) Nordisk forskning om public service. Radio och TV $i$ allmänhetens tjänst. Göteborg: Nordicom, pp. 9-18.

Jansson, André (2001) Image Culture. Media, Consumption and Everyday Life in Reflexive Modernity. Göteborg: JMG.

Jhally, Sut \& Bill Livant (1986) 'Watching as Working: The Valorization of Audience Consciousness', in Journal of Communication, vol 36: 3, pp. 124-143.

Lundkvist, Sven (1977) Folkrörelserna i det svenska samhället 1850-1920. Stockholm: Almqvist \& Wiksell International.

Marx, Karl (1867/1974) Kapitalet. Kritik av den politiska ekonomin. Första boken: Kapitalets produktionsprocess. Lund: Arkiv Zenit.

Meehan, Eileen R. (2000) 'Leisure or labor?: Fan Ethnography and Political Economy', in Ingunn Hagen \& Janet Wasko (eds) Consuming Audiences? Production and Reception in Media Research. Creskill, N.J.: Hampton Press, pp. 71-92

Mortensen, Frands (1977) 'The Bourgeois Public Sphere', in Mie Berg, Pertti Hemanus, Jan Ekecrantz, Frands Mortensen \& Preben Sebstrup (eds) Current Theories in Scandinavian Mass Communication Research. Grenaa: GMT, pp. 292-355.

Mosco, Vincent \& Lewis Kaye (2000) 'Questioning the Concept of the Audience', in Ingunn Hagen \& Janet Wasko (eds) Consuming Audiences? Production and Reception in Media Research. Creskill, N.J.: Hampton Press, pp. 31-46.

Murdock, Graham (2000) 'Peculiar Commodities: Audiences at Large in the World of Goods', in Ingunn Hagen \& Janet Wasko (eds) Consuming Audiences? Production and Reception in Media Research. Creskill, N.J.: Hampton Press, pp. 47-70.

Paterson, Richard (2001) 'Work Histories in Television', in Media, Culture \& Society, vol. 23, pp. 495-520.

Robins, Kevin \& James Cornford (1992) 'What is “Flexible” About Independent Producers?', in Screen vol. 33:2, pp. 190-200.

Skogerbø, Eli (2001) 'Sponsing i Reisesjekken. Finansieringsform og fordelningsmekanisme’, in Eva Bakøy \& Trine Syvertsen (eds) Sjekking på TV. Offentlig ydmykelse eller bare en lek. En studie av Reisesjekken - programformat, delttakere, produsenter, sponsorer og publikum. Oslo: Unipub, pp. 189-210.

Skovmand, Michael (1992) 'Barbarous TV International. Syndicated Wheels of Fortune', in Michael Skovmand \& Kim Christian Schrøder (eds) Media Cultures. Reappraising Transnational Media. London \& New York: Routledge, pp. 84-103.

Smythe, Dallas W. (1977) 'Communications: Blindspot of Western Marxism', in Canadian Journal of Political and Social Theory, vol. 1, pp. 120-127.

Syvertsen, Trine (1990) 'Kringkasting i 1990-åra: hvem er mest “public service”?', in Ulla Carlsson (ed.) Medier - människor - samhälle. Göteborg: Nordicom.

Syvertsen, Trine (1996) 'TV2 i Norge 1992-1995. Strategi och programpolitikk i en moderne hybridkanal', in Olof Hultén, Henrik Søndergaard \& Ulla Carlsson (eds) Nordisk forskning om public service. Radio och TV $i$ allmänhetens tjänst. Göteborg: Nordicom, pp. 61-78.

Søndergaard, Henrik (2000) 'TV2 som hybridkanal', in Hanne Bruun, Kirsten Frandsen \& Henrik Søndergaard (eds) TV2 på skarmen. Analyser av TV2's programvirksomhed. Københamn: Samfundslitteratur, pp. 29-62.

Tetzlaff, David (1991) 'Divide and Conquer: Popular Culture and Social Control in Late Capitalism', in Media, Culture \& Society, vol. 13, pp. 9-33.

Tunstall, Jeremy (1993) Television Producers. London \& New York: Routledge.

van Zoonen, Liesbet (2001) 'Desire and Resistance: Big Brother and the Recognition of Everyday Life', in Media, Culture \& Society, vol. 23, pp. 669-677. 